\begin{tabular}{ccr} 
FOLIA & $\begin{array}{c}\text { ENTOMOLOGICA } \\
\text { ROVARTANI HÖZLEMÉNYEK A R ICA } \\
\text { Volume } 81\end{array} \quad 2020$ & pp. 11-16 \\
\hline
\end{tabular}

\title{
Black Pennant has reached the Carpathian Basin! The first occurrence of Selysiothemis nigra in Hungary \\ (Odonata: Libellulidae)
}

\author{
Ádám MÉszÁros \\ Eötvös Loránd University, Faculty of Science, Center of Environmental Sciences, \\ H-1117 Budapest, Pázmány Péter sétány 1/A, Hungary.E-mail: meszaros.adam@ecolres.hu
}

\begin{abstract}
A fresh, female specimen of Selysiothemis nigra (Vander Linden, 1825) (Odonata: Anisoptera: Libellulidae) was found on a meadow at Káptalantóti, on the Balaton Uplands, Hungary. The species is a well-known migrant from Africa and Asia. In Europe, it is known from coastal areas of the Mediterranean and the Black Seas. The first record from Hungary as well as from the Carpathian Basin is presented. With 2 figures.
\end{abstract}

Key words - dragonfly, Anisoptera, faunistics, migrant species

\section{INTRODUCTION}

Some dragonfly species are spreading north from Africa or from Southern Europe, and rapidly colonising new areas in Central Europe. Migrant Afrotropical, Aramic, or Mediterranean species of the family Libellulidae can be found in Europe, e.g. Diplacodes lefebvrii (Rambur, 1842) or Trithemis kirbyi Selys, 1891 (JANNi et al. 2020). Occurrence of the first individual of Trithemis annulata (Palisot de Beauvois, 1807) in Hungary was a great surprise in 2016, and it was the 65th dragonfly species recorded from Hungary in the last 50 years (FARKAS 2017, AmBRUs et al. 2018).

Selysiothemis nigra (Vander Linden, 1825) is the type species of the monotypic genus Selysiothemis Ris, 1897 within Libellulidae.

A lot is known about the distribution of S. nigra from UBoni et al. (2015 and references in it). It is a western and Central Palaearctic species ranging from the Taklamakan and Thar deserts and adjacent Central Asia and Pakistan in the east, across the arid-semiarid belt of southern Russia, the Ukraine, the Caucasus, the Levant, Iraq, the Arabian Peninsula to the Iberian Peninsula and Morocco in the west. The species is well adapted to desert and steppe conditions, breeding in various fresh and brackish water habitats (BORISOV 2005, WILDERMUTH \& 
MARTENS 2014). Most observations are based on nomadic and migrant adults, and very few records refer to reproduction (COMPTE SART 1960, Borisov 2005, Lohr 2005, Dijkstra \& Boudot 2010, Brochard \& van Der Ploeg 2013, DE KNIJF et al. 2013). In Iraq and south-western Tajikistan the species was found to be bivoltine (MORTON 1919, Borisov 2005).

The ecology of the species is well known in Europe (UBONi et al. 2015). However, S. nigra has recently been found in several countries of Europe for the first time, which means that its known range is expanding northwards, resulting in records e.g. from Ukraine (TYTAR 2007; MARTYNOV 2020), Bulgaria (Marinov 2000, Gashtarov \& Beshiov 2010), Romania (Benstead 2013, SKOLKa 2014), Spain (Boudot et al. 2009) and Italy (UBONi et al. 2015).

The first record of Selysiothemis nigra in Hungary is reported in this paper.

\section{MATERIAL AND METHODS}

A trip was organised to the vicinity of Káptalantóti, Balaton Uplands to observe rare butterfly species protected by law in Hungary, e.g. Maculinea teleius (Bergsträsser, 1779) (Lycaenidae). On 2 August 2020, around 17:30 a fresh female of $S$. nigra was found in a meadow, resting in the grass, and was captured alive by a net. It was identified on the field, photographs were taken on it (Figs 1-2). Then the specimen was placed into $70 \%$ ethanol.

The specimen is labelled as follows:

“HUNGARY, Veszprém county, Káptalantóti, 4651'03.7”N, 17²9’49.3”E, wet meadow, caught by net, 2 August 2020, leg. Csilla Körmendy, Ádám Mészáros, Barnabás Szegedy. Selysiothemis nigra (Vander Linden, 1825) det. Ádám Mészáros, 2020"

The voucher specimen is deposited in the Hungarian Natural History Museum, Budapest.

\section{RESULTS AND DISCUSSION}

Selysiothemis nigra is a very small Anisoptera species, sized as a small Sympetrum Newman, 1833 species, with body length $30-38 \mathrm{~mm}$. Males are black, females are sand-coloured. The wings are transparent, and their venation is particularly loose, there are fewer and larger cells than in other dragonfly species. The eyes are bluish below like other southern species, e.g. Crocothemis erythraea (Brullé, 1832), Sympetrum fonscolombii (Selys, 1840), Trithemis annulata. Females have contrasting black and yellow legs (DijKSTRA \& LEWINGTON 2006). Of the Central European fauna S. nigra can only be confused with Sympetrum danae (Sulzer, 1776). 
The location of the meadow near Káptalantóti is far from major transport routes, so accidental introduction of the individual is improbable. Next day the trip was continued, the meadow was rigorously scanned, but no further $S$. nigra individuals were found. On 2 and 3 August 2020 only one further dragonfly species was seen there: Orthetrum coerulescens (Fabricius, 1798), which is widespread throughout Hungary.

The Káli-medence (= basin), the small region of the Hungarian occurrence, hosts springs with high mineral content, these could be potential breeding sites for the species. In addition, some larger water bodies, e.g. Kornyi-tó (= lake) and quarry ponds are also found there; they might also offer suitable habitats for the larvae.

The hitherto closest occurrences of S. nigra to Hungary have been documented at the coastal regions of Slovenia and Croatia, ca $10 \mathrm{~km}$ far from the sea (BOUDOT \& DE KNIJF 2012). That is why the record presented here is so surprising in the centre of the Carpathian Basin, ca $210 \mathrm{~km}$ from the closest coast of the Mediterranean Sea.

The Italian "Parco delle Dote" (4552'35.0”N 1242'54.6” E), $40 \mathrm{~km}$ from the coast of Venice, was described as "the northernmost evidence of breeding Selysiothemis nigra worldwide" (UвоN et al. 2015). However, larvae of S. nigra are likely to be found in some rivers, and maybe in Utlyukskyi Estuary $\left(46^{\circ} 10^{\prime} 44.1^{\prime \prime} \mathrm{N} 34^{\circ} 55^{\prime} 54.8^{\prime \prime} \mathrm{E}\right)$ in Ukraine (MARTY NOV 2020). In fact, this formerly vulnerable species is not rare on the coastal areas of not only the Mediterranean Sea, but the Black and Azov Seas, too (GBIF Secretariat 2019). Another interesting record of this species was provided by L. Stelea, who photographed a male S. nigra on 2 July 2020 in Bucharest, Romania (44'23'57.9' N 26 07'59.5”E), approximately $110 \mathrm{~km}$ far from the Black Sea (UEDA 2020).

This is the first record of $S$. nigra from Hungary and, at the same time, the Carpathian Basin. With S. nigra there are 66 dragonfly species observed in Hungary since 1970, i.e. in the last 50 years.

The English name of Selysiothemis nigra is Black Pennant, German name is Schwarzer Baron. Proposed Hungarian name: vándor árnyszitakötő.

Acknowledgements - I would like to thank András Ambrus (Fertő-Hanság National Park, Sarród, Hungary) for valuable information about the species. Thanks are also due to Balázs Tóth, Ottó Merkl and Zoltán Vas (Hungarian Natural History Museum, Budapest, Hungary) for their useful comments. Thanks for the fieldwork to Csilla Körmendy (Budapest, Hungary) and Barnabás Szegedy (Káptalantóti, Hungary).

The author was supported by the ÚNKP-19-3 New National Excellence Program of the Ministry for Innovation and Technology. 

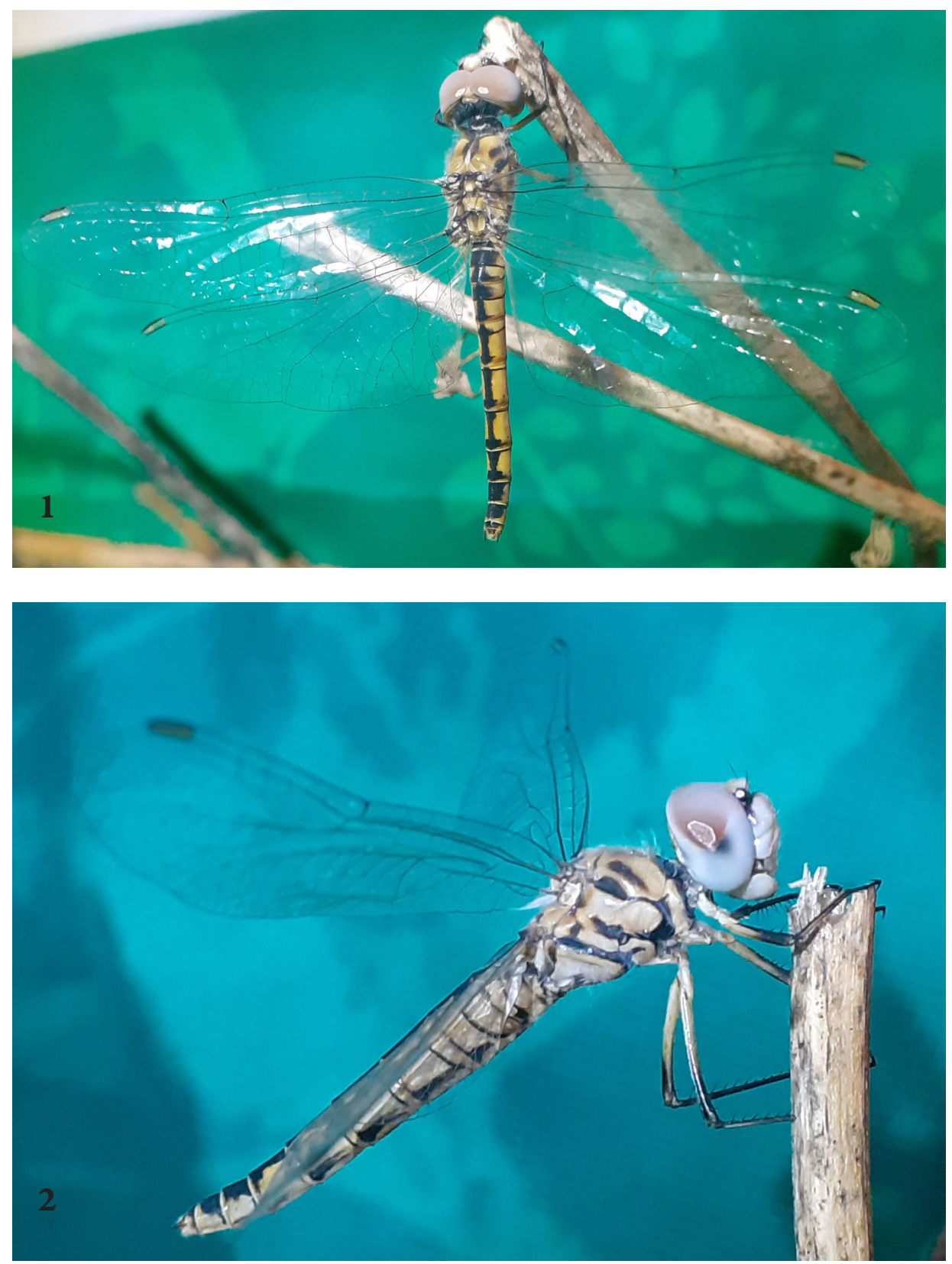

Figs 1-2. The first known Hungarian individual of Selysiothemis nigra (Vander Linden, 1825): alive female in Káptalantóti, 1 = dorsal view, 2 = lateral view (photo by Ádám Mészáros) 


\section{REFERENCES}

Ambrus A., Danyik T., Kovács T. \& Olajos P. 2018: Magyarország szitakötőinek kézikönyve. [Handbook of Hungarian damselflies and dragonflies.] - Magyar Természettudományi Múzeum, Herman Ottó Intézet, Budapest, 290 pp.

Benstead P. 2013: Birding Benstead. Birding in Bjäre and beyond. - Online:

http://birding-benstead.blogspot.com/search/label/Selysiothemis\%20nigra [Accessed 30 October 2020.]

BoRISOv S. N. 2005: Экомогия Selysiothemis nigra (Vander Linden, 1825) (Odonata, Libellulidae) в условиях пустынной зоны. (Ecology of Selysiothemis nigra (Vander Linden, 1825) (Odonata, Libellulidae) under desert conditions.) - Euroasian Entomological Journal 4(2): 95-100.

Boudot J.-P. \& De Knijf G. 2012: Nouvelles données sur les Odonates du Maroc oriental et méridional (Odonata). - Martinia 28: 1-28.

Boudot J.-P., Kalkman V. J., Azpilicueta Amorín M., Bogdanović T., Cordero Rivera A., Degabriele G., Dommanget J. L., Ferreira S., Garrigós B., Jović M., Kotarac M., Lopau W., Marinov M., Mihoković N., Riservato E., Samraoui B. \& Schneider W. 2009: Atlas of the Odonata of the Mediterranean and North Africa. Libellula Supplement 9: 1-256.

Brochard C. \& VAN DeR Ploeg E. 2013: Searching for exuviae of endemic Odonata species in Greece. - Brachytron 15: 83-101.

Compte Sart A. 1960: Biografia de la Selysiothemis nigra V.d.L. (Odonatos). - Graellsia 18: $73-115$.

De Knijf G., Vanappelghem C. \& Demolder H. 2013: Odonata from Montenegro, with notes on taxonomy, regional diversity and conservation. - Odonatologica 41: 1-29.

Dijkstra K.-D. B. \& Boudot J.-P. 2010: First update of the Atlas of the Odonata of the Mediterranean and North Africa: Orthetrum machadoi Longfield, 1955 new to the Palearctic and Agriocnemis sania Nielsen, 1959 new to the Egyptian Nile Valley. - Libellula 29: 107-125.

DijKstRA K.-D. B. \& Lewington R. 2006: Field guide to the dragonflies of Britain and Europe. British Wildlife Publishing, Gillingham, 320 pp.

FARKAS S. 2017: A Trithemis annulata (Palisot de Beauvois, 1807) előfordulása Magyarországon. (Occurrence of Trithemis annulata (Palisot de Beauvois, 1807) in Hungary.) - Folia bistorico-naturalia Musei Matraensis 41: 9-10.

Gashtarov V. \& Beshoov S. 2010: Lindenia tetraphylla (Vander Linden, 1825) (Odonata, Gomphidae) a new genus and species for the Bulgarian fauna. - The Entomologist's Record and Journal of Variation 122: 272-274.

GBIF SECRETARIAT 2019: Selysiothemis nigra Vander Linden, 1825. - GBIF Backbone Taxonomy. Checklist dataset accessed via GBIF.org https://www.gbif.org/species/1429541 https://doi.org/10.15468/39omei

Janni O., Viganò M. \& CoRso A. 2020: First records of Diplacodes lefebvrii (Rambur, 1842) for Sicily and additional record of Trithemis kirbyi Selys, 1891 (Odonata Libellulidae). Biodiversity Journal 11: 65-68. https://doi.org/10.31396/Biodiv.Jour.2020.11.1.65.68 
Lohr M. 2005: Selysiothemis nigra (Vander Linden, 1825) new for Portugal (Anisoptera: Libellulidae). - Notulae Odonatologicae 6: 57-58.

MARINOV M. 2000: Ажобен полеви определител на водните кончета на България. [A pоскеt field guide to the dragonflies of Bulgaria.] - Eventus, Sofia, $104 \mathrm{pp}$.

Martynov A. V. 2020: Some rare damselflies and dragonflies (Odonata: Zygoptera and Anisoptera) in Ukraine: new records, notes on distribution, and habitat preferences. Journal of Threatened Taxa 12(10): 16279-16294. htps://doi.org/10.11609/jot.5831.12.10.16279-16294

Morton K. J. 1919: Odonata of Mesopotamia. - The entomologist's monthly magazine (B) 55: 143-151, 183-196.

SKolKa M. 2014: Selysiothemis nigra (Odonata) - new species for Danube Delta. - In: Popa L. O., Adam C., Chişamera G., Iorgu E., Murariu D. \& Popa O. P. (eds): International Zoological Congress of "Grigore Antipa" Museum, 19-22 November 2014, Bucharest Romania. Book of abstracts. "Grigore Antipa" National Museum of Natural History, Bucharest, p. 122.

TytaR V. M. 2007: Selysiothemis nigra (Vander Linden, 1825) - новый вид стрекоз (Insecta: Odonata) Аля фауны Украины. (Selysiothemis nigra (Vander Linden, 1825) - a new species of dragonflies (Insecta: Odonata) for the fauna of Ukraine.) - Vestnik Zoologii 41:122.

UEDA K. 2020: Selysiothemis nigra Vander Linden, 1825. - iNaturalist Research-grade Observations. iNaturalist.org. Occurrence dataset accessed via GBIF.org https://www.gbif.org/occurrence/2823197501. https://doi.org/10.15468/ab3s5x

Uboni C., NADALON G. \& SCHRÖter A. 2015: Evidence of breeding of Selysiothemis nigra in the regions of Friuli Venezia Giulia and Veneto, northeastern Italy (Odonata: Libellulidae). Notulae Odonatologicae 8 (5): 117-155.

Wildermuth H. \& Martens A. 2014: Taschenlexikon der Libellen Europas. - Quelle \& Meyer, Wiebelsheim, $824 \mathrm{pp}$. 